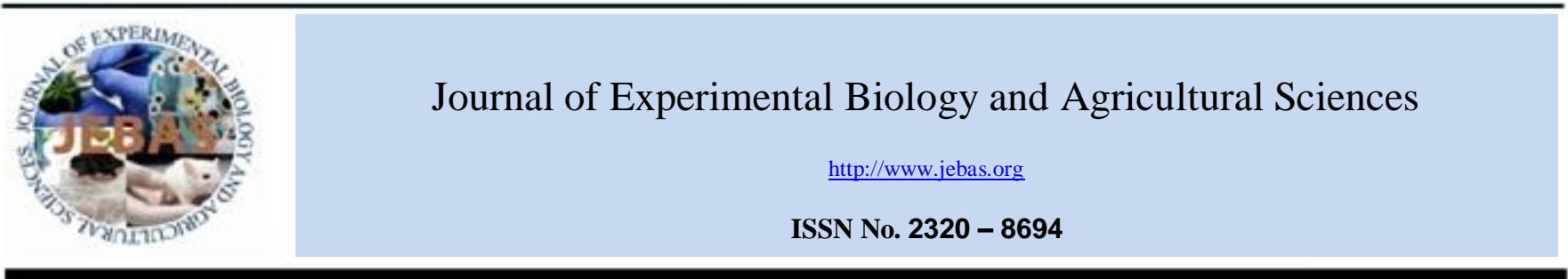

\title{
MATHEMATICAL PROGRAMMING MODELS FOR OPTIMUM ENTERPRISE COMBINATION IN THE HOMESTEADS OF SOUTHERN LATERITE AGRO ECOLOGICAL UNIT
}

\author{
Muhammed Jaslam PK ${ }^{* 1}$, Brigit Joseph ${ }^{1}$, Vijayaraghava Kumar ${ }^{1}$, Jacob John², Paul Lazarus T ${ }^{3}$ \\ ${ }^{1}$ Department of Agricultural Statistics, College of Agriculture, Vellayani, Kerala Agricultural University, Thrissur- 680656, India \\ ${ }^{2}$ Integrated Farming Systems Research Station, Karamana, Kerala Agricultural University, Thrissur- 680656, India \\ ${ }^{3}$ Department of Agricultural Economics, College of Agriculture, Vellayani, Kerala Agricultural University, Thrissur- 680656, India
}

Received - September 25, 2017; Revision - November 25, 2017; Accepted - December 07, 2017

Available Online - December 27, 2017

DOI: http://dx.doi.org/10.18006/2017.5(6).831.839

KEYWORDS

Linear Programming

Homestead

Optimum Model

Sensitivity Analysis

\begin{abstract}
Farm management is one of the most decisive factors in production and marketing of agricultural crops. In a broad depiction, management is defined as making decision process through which the limited resources are allocated to competent items in such a way that the determined goal can be achieved. Mathematical programming especially linear programming supports farmers for efficient decisions in the field of allocating limited resources to competent activities. This research paper was carried out with the objectives of examining and developing statistical models for homestead farming systems in the southern laterite agro-ecological units (AEU8) of Thiruvananthapuram District and to suggest suitable cropping/farming system models that maximize farm income by the optimal use of available resources. The optimum model worked out for $\mathrm{S}_{\mathrm{I}}$ (crop only) in AEU8 consisted of binding solution for almost all the enterprises except some enterprises like coconut and banana with 25.30 per cent enhancement in net return as compared to net return from the existing plan. The optimum model for $\mathrm{S}_{2} \mathrm{HFS}$ was also similar to that of $S_{1}$ with non-binding solution for coconut and poultry with 31.30 per cent increase in net return. However, sensitivity analysis of the optimum model revealed that further enhancement of net return could be achieved by increasing the cropping intensity in the underutilized intercropped area and changing the binding enterprises.
\end{abstract}

* Corresponding author

E-mail: pkjaslamagrico@gmail.com (Muhammed Jaslam PK)

Peer review under responsibility of Journal of Experimental Biology and Agricultural Sciences.

Production and Hosting by Horizon Publisher India [HPI] (http://www.horizonpublisherindia.in/).

All rights reserved.
All the article published by Journal of Experimental Biology and Agricultural Sciences is licensed under a Creative Commons Attribution-NonCommercial 4.0 International License Based on a work at www.jebas.org.

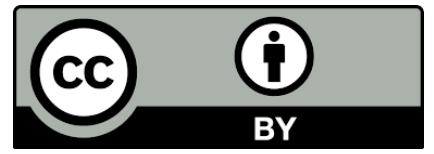




\section{Introduction}

Homestead farming has been the backbone of agricultural economy of Kerala, owing to its direct and indirect benefits to the social and economic well-being of the people in State over the years, both at the micro and macro levels. The homesteads of Kerala, is considered as a self-sustainable mini-production model, is at present in the verge of extinction due to the share of land under homestead farming in Kerala has grown, but the share of area under garden land has declined, owing to rapid urbanization. Over the years, many small holdings have fragmented into smaller homesteads. Farmers depending on farming alone were found in distress due to low and fluctuating income. Increasing population and low per capita availability of lands have necessitated better management practices in home gardens and the micro-development models like homesteads is the key to success in a populous country like India.

Conventional home gardens were handled irrationally without any planning and with very low resource use efficiency. Though Kerala used to be an agrarian State; Agriculture has ceased to be the most important economic activity. The Situation Assessment Survey of Agricultural Households conducted at national level in NSSO $70^{\text {th }}$ round (January-December 2013) revealed that Kerala had the least percentage share of agricultural households in the country i.e. 27.3 per cent and nearly, 61 per cent of the agricultural households reported to have earned income from activities other than agricultural activities. Mere 16 per cent reported cultivation as foremost source of income and 0.6 per cent reported livestock as chief source of income.

The Kerala State has been delineated in to 23 Agro Ecological Units (AEUs) by the National Bureau of Soil Survey and Land Use planning, Bangalore (2012) based on climatic conditions and nature of soil, which is most ideal for formulating any policy or programme to improve location specific cropping system across the State (Kurian, 2012). It is essential to prepare strategies and action plan for each AEU for the development of agriculture and allied sectors

In agriculture, like in any other business, the efficiency is accomplished by an optimum utilization of resources such as land, labour, capital etc.. Optimum allocation of land and other resources involves decisions regarding what crops to produce, how much land to allot to each crop activity and what strategy and combination of inputs to each crop so that the farm return is maximum. In this perspective, it is necessary that the available scarce resources should be used economically and efficiently. The efficiency of farming depends on such combination of inputs that is most economical to secure a given output. The efficiency of given resources is said to be greater when higher the output for unit input and conversely greater the efficiency of resources when lower the input per unit of output. The maximization of efficiency is therefore a criterion for maximizing the profit. Relating to this, according to Hassan et al. (2015) the only way to meet rising demand of food, fibre and fuel for the ever increasing population is by increasing productivity which is probable by more systematic utilization of the resources and their optimal allocation to get maximum returns.

Mathematical programming tools have been employed to model mixed farming, horticultural crops, and livestock alone, various breeds and varieties, and all sorts of combinations of different activities in homesteads (Mehta, 1992). Mathematical programming, also known as mathematical optimization model, is the selection of a best element from available alternatives. Optimization is the act of achieving the finest possible result under given situation. The goal of all such decisions is either to minimize effort or to maximize benefit. The effort or the benefit can be usually expressed as a function of certain design variables. Hence, optimization is the method of finding the situation that gives the maximum or the minimum value of a task.

Jayachandran (1985) worked out optimal plans on garden land farms by studying 72 holdings chosen from Ollukkara Block of Thrissur District, Kerala. He found that optimal plans resulted in more efficient use of resources by mixing three enterprises viz. coconut, banana and cow. Jacob \& Nair (1999) worked out an ideal Integrated Farming System (IFS) model through linear programming for farmers with holding size 0.2 ha and less, constitute of 43 ventures with a cropping intensity of 161 per cent and $\mathrm{B} C$ ratio of $1: 2.5$.

Dey \& Mukhopadhyay (2010) applied linear programming to revise allocation of vegetable crops in an optimum manner at Kakdwip block of South Parganas District in West Bengal. In the optimal crop plan, more resources were allocated for brinjal and pointed gourd. Net return received from optimal crop plan enhanced 49.79 percent over the net return earned in existing crop. Majeke et al. (2013) developed a linear programming model to determine the optimal crop combination for a rural farmer in Zimbabwe. Crops considered were maize, soyabeans and cotton. The model produced an optimal crop combination which gave a higher income compared to the farmer's plan. The income difference was 73 per cent.

In this context, the present study is an attempt to analyze the possibilities and prospects of increasing farm profitability by rational resource allocation through the application of statistical modeling that enhances sustainable production in homesteads. 


\section{Materials and methods}

The present study was conducted at Department of Agricultural Statistics, College of Agriculture, Vellayani. Trivandrum District was selected purposively for the present study and from the district southern laterite agro-ecological units (AEU 8) was selected at the first stage and two panchayaths ( Kulathoor and Karode) with maximum number of homesteads was purposively identified as the second stage units from the selected agroecological unit. At the third stage 26 homesteads having similar type of farming systems and holding size between 0.1-0.3 ha was selected at random from the selected panchayats. The data was collected during the period 2016-2017. The selected homesteads were classified into two, based on the existing homesteads farming /cropping system (HFS) named as System-I ( $\left.\mathrm{S}_{1}\right)$, consisting of crops alone and System-II $\left(\mathrm{S}_{2}\right)$ consisting of crops, poultry and goat $\left(\mathrm{S}_{1}+\right.$ poultry+ goat).

The benefit-cost analysis was worked out for average farm size of $S_{1}$ and $S_{2}$ by considering, different costs and returns incurred in cultivation of crop as well as rearing livestock and poultry. Cost of cultivation is taken into account in the case of annuals and biennials, whereas only maintenance cost is considered for perennials, goat and poultry and per unit net return of each enterprise was determined.

Linear programming (LP) which is developed by Dantzig (1991) were applied to analyse the data generated through the survey, consisting of optimization of a linear objective function subjected to a number of linear equality and inequality constraints. In the present study, the linear objective function was developed by considering the various activities/ enterprises as variables and unit net return of these enterprises as the coefficients of the variables and the objective function was maximized by using the linear constraints developed. $\mathrm{S}_{1}$ and $\mathrm{S}_{2}$ was developed by considering the unit net return of the enterprises/ activities in the homesteads. A general form of maximization of an LP model can be developed in the following manner.

\subsection{Mathematical formulation of the model}

\subsubsection{Objective Function}

The role of objective function in this study was to maximize the net income from the homesteads subjected to the specified constraints in the model. The objective function for $S_{1}$ is given as

Maximize $Z=c_{1} x_{1}+c_{2} x_{2}+\ldots .+c_{n} x_{n}$

Where, $\mathrm{x}_{1}, \mathrm{x}_{2} \ldots \mathrm{x}_{\mathrm{n}}$ represents the homestead enterprises and $\mathrm{c}_{1}, \mathrm{c}_{2}, \ldots, \mathrm{c}_{\mathrm{n}}$ are unit net return associated to the enterprises.

\subsubsection{Constraints}

The constraints in the objective function are linear functions of the variables represented by the following form

$\sum_{j=1}^{n} a_{i j} x_{j} \leq o r=o r \geq b_{i}$

$x_{j}, b_{j} \geq 0$ (Non negativity condition)

The constraints included in the study are

\subsubsection{Population Constraints of each enterprise}

The constraints with respect to the population of different enterprises included in the model were decided so as to meet the multiple demand of the farm family by enterprise diversification, optimize the available resources and maximize the gross returns. Modal value, of farmer's preference to the different enterprises was considered for developing the population constraint. This forms an identity matrix in the LHS (Left hand side) and the RHS (right hand side) is a column matrix of order with model values each activity. In order to develop constrains for vegetables, all the vegetables were grouped into a single unit and a maximum of two units from which two units was considered in the inequality constraint of vegetables. All the enterprises in $S_{1}$ were converted into linear constraints with RHS as populations (last column) in Table 1 and for $S_{2}$ last column in Table 2 .

\subsubsection{Total area}

The model is developed for a holding size of 0.18 ha homestead (average homestead size in AEU 8) which includes area of house and permanent structures, net cropped area and uncultivated land.

\subsubsection{Intercropped area}

The inter space accessible was assessed after excluding the area occupied by the house and permanent structures and the area occupied by the basins of coconut and other tree components.

\subsubsection{Investment amount}

All the activities are financed internally and the farmer is not dependent upon external financing in the form of credit. The third quartile value of the investment/ total expenditure was considered while developing the model rather going for higher value of the investment by the homestead farmers of each system.

Simplex iteration algorithm was used to solve the formulated LP models with the help of Optimization Modeling Software, LINGO 11.0. 


\subsection{Sensitivity Analysis}

The sensitivity analysis was carried out to determine the feasibility range of available resources in terms of R.H.S of the constraints and shadow price due to change in objective function Coefficients in the optimal model of LP.

\section{Results and Discussion}

The average holding size of homesteads was 0.18 ha (45 cents/1800 $\mathrm{m}^{2}$ ) in AEU 8. Economics of cultivation including operational cost, gross return, net return and benefit-cost ratio of all enterprises were worked out and the estimated total net return of the existing HFS $S_{1}$ and $S_{2}$ was ₹27,596/- and ₹55,244/- respectively. The B: C ratio of $S_{1}$ and $S_{2}$ were 2.11 and 2.14

\subsection{Optimum Model for $S_{1}$ Homestead Cropping System}

The optimum homestead model for $S_{1}$ is presented in Table 1 . The optimum model of LP consisted of all enterprises with binding solution i.e., population in RHS of linear constraints for almost all the enterprises except for the major enterprises like coconut and banana. The benefit cost ratio obtained for the model was 2.2. The optimum model suggested a minimum number of 15 coconuts palms in the presence of other linear constraints. Moreover, in the optimal solution, crops such as banana, turmeric and colocasia were non-binding i.e., it is not possible to increase the population up to the suggested limit, due to the limitation in available investment amount.

Table 1 Optimum L P Homestead cropping model of $\mathrm{S}_{1}$ in AEU 8

\begin{tabular}{|c|c|c|c|c|c|c|c|c|c|c|}
\hline \multirow{2}{*}{$\begin{array}{c}\text { S. } \\
\text { No }\end{array}$} & \multirow{2}{*}{ Enterprise } & \multirow{2}{*}{ Population } & \multicolumn{2}{|c|}{ Space $\left(\mathbf{M}^{2}\right)$} & \multicolumn{2}{|c|}{ Expenditure (₹) } & \multicolumn{2}{|c|}{ Gross Return (₹) } & \multirow{2}{*}{$\begin{array}{c}\text { Net } \\
\text { Return (₹) }\end{array}$} & \multirow{2}{*}{ Constraints } \\
\hline & & & Unit & Total & Unit & Total & Unit & Total & & \\
\hline \multicolumn{11}{|c|}{ Main Area } \\
\hline 1 & Coconut & 15 nos. & 21.77 & 326.61 & 188.03 & 2820.51 & 330.23 & 4953.44 & 2132.93 & $15 \geq \leq 30$ \\
\hline 2 & Jack & 2 nos. & 12.98 & 25.96 & 205.26 & 410.51 & 643.5 & 1287 & 876.49 & $\leq 2$ \\
\hline 3 & Mango & 2 nos. & 4.03 & 8.07 & 301.01 & 602.01 & 707.67 & 1415.35 & 813.33 & $\leq 2$ \\
\hline 4 & Gooseberry & 2 nos. & 18.24 & 36.47 & 175.59 & 351.19 & 616.04 & 1232.08 & 880.89 & $\leq 2$ \\
\hline 5 & Tamarind & 2 nos. & 38.47 & 76.93 & 245.73 & 491.47 & 762.88 & 1525.76 & 1034.29 & $\leq 2$ \\
\hline 6 & Bread Fruit & 1 no. & 67.89 & 67.89 & 144.3 & 144.3 & 383.96 & 383.96 & 239.66 & $\leq 1$ \\
\hline 7 & Cashew & 2 nos. & 57.79 & 115.58 & 437.71 & 875.43 & 923.04 & 1846.08 & 970.65 & $\leq 2$ \\
\hline 8 & Arecanut & 3 nos. & 8.04 & 24.12 & 128.63 & 385.88 & 410.84 & 1232.51 & 846.63 & $\leq 3$ \\
\hline 9 & $\begin{array}{l}\text { House \& } \\
\text { Permanent } \\
\text { Structures } \\
\end{array}$ & 1 & 378.57 & 378.57 & - & - & - & - & - & 1 \\
\hline \multicolumn{11}{|c|}{ Interspaces } \\
\hline 10 & Tapioca & 108nos. & 0.87 & 93.47 & 32.08191 & 3464.85 & 67.69383 & 7310.93 & 3846.09 & $40 \geq \leq 108$ \\
\hline 11 & Banana & 47 nos. & 2.4 & 112.99 & 181.7047 & 8540.12 & 372.18 & 17492.46 & 8952.34 & $\leq 60$ \\
\hline 12 & Pepper & 10 nos. & 0.5 & 5.02 & 124.7867 & 1247.87 & 347.9375 & 3479.37 & 2231.51 & $\leq 10$ \\
\hline 13 & Ginger & 8 nos. & 0.34 & 2.74 & 4.99886 & 39.99 & 12.22 & 97.76 & 57.77 & $\leq 7$ \\
\hline 14 & Turmeric & 7 nos. & 0.92 & 6.41 & 9.245 & 64.72 & 15.35836 & 107.51 & 42.79 & $\leq 12$ \\
\hline 15 & Papaya & 13 nos. & 2.01 & 26.12 & 65.02993 & 845.39 & 154.6806 & 2010.85 & 1165.46 & $\leq 13$ \\
\hline 17 & Moringa & 2 nos. & 2.83 & 5.67 & 23.13063 & 46.26 & 59.93 & 119.86 & 73.6 & $1 \geq \leq 2$ \\
\hline 18 & Colocasia & 5 nos. & 0.98 & 4.92 & 22.34 & 111.7 & 40.95563 & 204.78 & 93.08 & $5 \geq \leq 14$ \\
\hline 18 & Dioscorea & 12 nos. & 0.64 & 7.63 & 27.7375 & 332.85 & 61.43345 & 737.2 & 404.35 & $\leq 12$ \\
\hline 19 & Amorphophallus & 18 nos. & 1.06 & 19.01 & 32.673 & 588.11 & 94.06997 & 1693.26 & 1105.15 & $\leq 18$ \\
\hline 20 & Sapota & 1 no. & 10.17 & 10.17 & 175.8228 & 175.82 & 318.686 & 318.69 & 142.86 & $\leq 1$ \\
\hline 21 & Annona & 1 no. & 7.07 & 7.07 & 190.1623 & 190.16 & 445.3925 & 445.39 & 255.23 & $\leq 1$ \\
\hline 22 & Guava & 2 nos. & 4.52 & 9.04 & 372.2715 & 744.54 & 930.7167 & 1861.43 & 1116.89 & $1 \geq \leq 2$ \\
\hline 23 & Vegetables & 2 unit & 40 & 80 & 3159.503 & 6319.01 & 6807.056 & 13614.11 & 7295.11 & $\leq 2$ \\
\hline & Inter space Total & & & 390.27 & & & & & & $\leq 677.44$ \\
\hline & Main area Total & & & 1060.21 & & & & & & $\leq 1800.00$ \\
\hline & Grand Total & & & 1450.48 & & 28792.68 & & 63369.77 & 34577.09 & \\
\hline
\end{tabular}

Journal of Experimental Biology and Agriculture Science http://www.jebas.org 
The optimum model developed for a homestead farmer in $\mathrm{S}_{1}$ of AEU 8 by investing an amount of ₹ $28,793 /-$ would receive a net profit of ₹ 34,577/- which indicates 25.30 per cent enhancement in net profit over the existing plan. The optimum model left a total area of $439.79 \mathrm{~m}^{2}$ with unutilized interspaced area of $390.27 \mathrm{~m}^{2}$, which is an indication of laps in proper farm planning. Furthermore, the underutilized area may be effectively utilized by planting more crops by allowing sufficient area for house and permanent structures and investing more amounts, which in turn may increase the cropping intensity as well as farm income. The functional diversity of the components may be selected by giving due importance to family preferences and interests to meet the livelihood of the farm household.

\subsection{Optimum model for $S_{2}$ homestead farming system}

The optimum model for $\mathrm{S}_{2}\left(\mathrm{~S}_{1+}\right.$ goats + poultry $)$ was also developed for an average homestead of size 45 cents with the linear objective function consisting of two additional variables in linear objective function of $S_{1}$, one for goat and one for poultry with per unit net return as coefficients. The functional diversity of the components included in the homesteads was preferably selected by the farmers, giving due importance to the family requirement, taste, interest and market demand for the enterprises. In $S_{2}$, there were two more inequality constraints related to goat and poultry. The linear inequality constraints of livestock/poultry components of the model in $S_{2}$ comprised a value of 2 to less than or equal to 4 for goats and 4 to 6 for poultry. According to Salam et al. (1992), LP solutions were mostly recommended for perennial crops due to high preference by farmers since their expenditure in terms of labour and input cost was less. In the present study also, all the perennial crops were observed with binding solution, subjected to all other constraints. The optimum model for average $\mathrm{S}_{2}$ homesteads in AEU 8 comprising of 28 enterprises including house and permanent structures is presented in Table 2.

The livestock/poultry unit in the optimum model in $\mathrm{S}_{2}$ comprised of 4 goats and 6 poultry. In the optimum model, goat unit had a great role in raising the farm income by way of selling kids and poultry unit in most of the $\mathrm{S}_{2}$ homesteads provided eggs and meat required for the farm family. The population constraint for coconut as per the preference of farmers was within a range of 18 to 30 palms. The optimum model suggested cultivation of minimum number of coconut palms keeping in, the view of other constraints, land requirement and investment amount. The optimal solution for coconut, colocasia, poultry and vegetables did not allow increasing the population up to suggested limit, due to the constraint of scarce available investment capital. For all other enterprises, binding solution was obtained in the optimum model. The optimum model worked out for $\mathrm{S}_{2}$ in AEU8 was found to have binding solution for almost all the enterprises except some enterprises like coconut, colocasia, poultry and vegetables with a B: C ratio of 1.95 .

The optimum LP model developed by investing an amount of ₹63,064.45/-by the $S_{2}$ homestead farmer would receive a net profit of ₹72,535.78/- which indicates an enhancement of 31.30 per cent in net return as compared with the net return from the existing plan. However, the available area in the homestead was underutilized by all enterprises including area for house and permanent structures in the optimum model with two vegetable units. It may be concluded that, there is a possibility of enhancing income further by increasing the population of enterprises which may or may not require additional capital investment. The possibility of incorporating all enterprises in the suggested or a greater limit by additional investment in capital will be discussed in the upcoming sections.

\subsection{Sensitivity analysis of $S_{1}$ model}

Sensitivity analysis of the $S_{1}$ model of AEU 8 is presented in Table 3, exposed minimum and maximum range of net income for each enterprise, where the optimal LP solution will remain unchanged within these range of values of the enterprises. The value of coconut in the optimal plan was fifteen when the unit net return of coconut palm was ₹142.2/- and the model remains stable until the unit net income reaches ₹197.12/-. Similarly for banana and turmeric, the maximum range allowable increase in unit net return was ₹201.47/- and ₹9.69/- respectively. However, in the case of binding enterprises, the optimal LP model will be same until the net return reduces to certain limit as specified in Table 3. For example, in the case the binding enterprises jack and mango, the optimum model will be same until the unit net return reduces to ₹215.17/- and ₹315.54/- respectively.

It is obvious from the sensitivity analysis of the model that, several changes could be suggested to increase the farm income, if the farmer's constraints are removed or change the RHS of the constraints in terms of available resources. The shadow price values (unit worth of resources) indicates the increase or decrease in the gross returns of the LP model for a unit change in value of the constraint within the given range of minimum and maximum of RHS and these values are presented in Table 3. In the case of expenditure, third quartile (₹28,820.03/-) was taken as the RHS of investment amount for LP modeling and the sensitivity analysis reported that, if the farmer is ready to invest an amount up to ₹31,154.85/-, for which the farmer would receive ₹1.05/- on every one rupee additional investment on the existing homesteads. The unit worth of resource of jack, gooseberry and tamarind was ₹223.08/-, ₹256.38/- and ₹259.55/- suggested that one unit increase in the population of these enterprises would enhance 
Table 2 Optimum L P Homestead cropping model of $S_{2}$ in AEU 8

\begin{tabular}{|c|c|c|c|c|c|c|c|c|c|c|}
\hline \multirow{2}{*}{$\begin{array}{l}\text { S. } \\
\text { No }\end{array}$} & \multirow{2}{*}{ Enterprise } & \multirow{2}{*}{ Value } & \multicolumn{2}{|c|}{ Space $\left(\mathbf{M}^{2}\right)$} & \multicolumn{2}{|c|}{ Expenditure (Rs) } & \multicolumn{2}{|c|}{ Gross Return(Rs) } & \multirow{2}{*}{$\begin{array}{c}\text { Net } \\
\text { Return } \\
\text { (Rs) }\end{array}$} & \multirow[b]{2}{*}{ Constraints } \\
\hline & & & Unit & Total & Unit & Total & Unit & Total & & \\
\hline \multicolumn{11}{|c|}{ Main Area } \\
\hline 1 & Coconut & 18 nos. & 12.25 & 220.46 & 189.2 & 3405.58 & 345.4599 & 6218.28 & 2812.7 & $18 \geq \leq 40$ \\
\hline 2 & Jack & 2 nos. & 9.4 & 18.8 & 315.87 & 631.73 & 1151.15 & 2302.3 & 1670.57 & $1 \geq \leq 2$ \\
\hline 3 & Mango & 3 nos. & 7.67 & 23 & 227.21 & 681.62 & 662.61 & 1987.83 & 1306.21 & $2 \geq \leq 3$ \\
\hline 4 & Gooseberry & 2 nos. & 15.9 & 31.79 & 202.36 & 404.72 & 448.5342 & 897.07 & 492.35 & $1 \geq \leq 2$ \\
\hline 5 & Tamarind & 2 nos. & 20.42 & 40.84 & 298.54 & 597.07 & 881.65 & 1763.3 & 1166.23 & $1 \geq \leq 2$ \\
\hline 6 & Bread Fruit & 2 nos. & 15.31 & 30.61 & 166.32 & 332.64 & 420.33 & 840.66 & 508.02 & $1 \geq \leq 3$ \\
\hline 7 & Cashew & 3 nos. & 50.24 & 7 & 390.66 & 1171.99 & 753.42 & 2260.26 & 1088.27 & $1 \geq \leq 2$ \\
\hline 8 & Goat & 4 nos. & 7 & 3 & 5497.02 & 21988.07 & 13248.51 & 52994.05 & 31005.99 & $2 \geq \leq 4$ \\
\hline 9 & Poultry & 6 nos. & 3 & 3 & 1425 & 8550 & 2290.17 & 13741.01 & 5191.01 & $6 \geq \leq 15$ \\
\hline 10 & $\begin{array}{l}\text { House \& Permanent } \\
\text { Structures }\end{array}$ & 1 & 372 & 372 & - & - & - & & - & 1 \\
\hline \multicolumn{11}{|c|}{ Interspaces } \\
\hline 11 & Tapioca & 80 nos. & 1.2 & 95.78 & 32.9 & 2632.14 & 67.47928 & 5398.34 & 2766.2 & $60 \geq \leq 80$ \\
\hline 12 & Clove & 1 no. & 3.33 & 3.33 & 249.99 & 249.99 & 762.215 & 762.21 & 512.22 & $\leq 1$ \\
\hline 13 & Banana & 62 nos. & 1.72 & 106.61 & 167.39 & 10377.94 & 327.939 & 20332.22 & 9954.27 & $15 \geq \leq 62$ \\
\hline 14 & Nutmeg & 1 no. & 11.82 & 11.82 & 379.95 & 379.95 & 879.4788 & 879.48 & 499.53 & $\leq 1$ \\
\hline 15 & Pepper & 18 nos. & 0.38 & 6.92 & 120.15 & 2162.75 & 320.3867 & 5766.96 & 3604.21 & $\leq 18$ \\
\hline 16 & Ginger & 3 nos. & 0.31 & 0.93 & 7.4 & 22.21 & 14.565 & 43.7 & 21.49 & $\leq 3$ \\
\hline 17 & Curry Leaf & 1 no. & 1.41 & 1.41 & 19.72 & 19.72 & 71.25 & 71.25 & 51.53 & $\leq 1$ \\
\hline 18 & Papaya & 20 nos. & 1.77 & 35.33 & 80.35 & 1606.96 & 184.2718 & 3685.44 & 2078.47 & $2 \geq \leq 20$ \\
\hline 19 & Moringa & 2 nos. & 1.77 & 3.53 & 61.82 & 123.64 & 131.61 & 263.22 & 139.58 & $\leq 2$ \\
\hline 20 & Colocasia & 5 nos. & 0.58 & 2.9 & 37.6 & 188.01 & 54.96743 & 274.84 & 86.82 & $5 \geq \leq 12$ \\
\hline 21 & Dioscorea & 12 nos. & 0.64 & 7.63 & 30.32 & 363.8 & 56.67752 & 680.13 & 316.33 & $8 \geq \leq 12$ \\
\hline 22 & Amorphophallus & 10 nos. & 0.48 & 4.78 & 62.93 & 629.27 & 205.2117 & 2052.12 & 1422.85 & $2 \geq \leq 10$ \\
\hline 23 & Sapota & 2 nos. & 6.6 & 13.2 & 204.08 & 408.16 & 406.759 & 813.52 & 405.36 & $1 \geq \leq 2$ \\
\hline 24 & Annona & 2 nos. & 7.07 & 14.13 & 262.11 & 524.22 & 513.0293 & 1026.06 & 501.84 & $1 \geq \leq 2$ \\
\hline 25 & Bilimbi & 2 nos. & 1.72 & 3.44 & 37.22 & 74.44 & 107.7362 & 215.47 & 141.03 & $\leq 2$ \\
\hline 26 & Guava & 1 no. & 8.04 & 8.04 & 250.61 & 250.61 & 521.0912 & 521.09 & 270.48 & $\leq 1$ \\
\hline 27 & Pineapple & 10 nos. & 0.5 & 5.02 & 13.39333 & 133.93 & 29.43 & 294.3 & 160.37 & $\leq 10$ \\
\hline 28 & Vegetables & 2 unit & 26 & 52 & 2576.634 & 5153.27 & 4757.57 & 9515.14 & 4361.87 & $1 \geq \leq 3$ \\
\hline & Interspace total & & & 376.81 & & & & & & $\leq 935.69$ \\
\hline & Total main area & & & 750.5 & & & & & & $\leq 1800.00$ \\
\hline & Grand total & & & 1127.31 & & 63064.45 & & 123214.7 & 72535.78 & \\
\hline
\end{tabular}

farm income substantially. However, the increase in the population of these enterprises or tree crops invades the concept of homesteads. While the shadow price ₹ 335.5 /- of vegetable unit recommending the possibility of expanding vegetable area in the homesteads which may be more acceptable than of increasing the population of perennial tree crops.

Homestead area in the model was found to be an abundant resource with non binding constraints for area and hence the shadow price was zero. The shadow price of non binding enterprises would always be zero indicating that, the there is no meaning in increasing the abundant resources. However, an increase in the population of the enterprises having high shadow price will give more return, but at the expense of other enterprises which are more remunerative.

The optimum LP model and the sensitivity analysis of $S_{1}$ indicated that maximum net return has been achieved by 
increasing the population of farmer preferred enterprises in a lesser cultivated area of homesteads.

\subsection{Sensitivity Analysis of $S_{2}$ model}

Sensitivity analysis of the $S_{2}$ model of AEU 8 presented in Table 4 showed range of net income of each enterprise where, values of the enterprises in the optimal LP solution will remain unchanged within these range. The optimal plan comprised of 4 goats and it remains valid even if the unit net income reduced to ₹4,652.84/from the net return of ₹7,751.50/- in the existing plan. Similarly for black pepper, the number of pepper vines in the homesteads in the optimal plan remains unchanged until the unit net return reduced to half of the existing income. Home stead farmers preferred to cultivate banana ( 62 ), tapioca (80) and to rear 4 goats even if the unit net return reduced to ₹141.68/-, 27.85/-, and $4,652.84$ respectively. Similar trend was noticed for all binding enterprise in the optimum model. The value of non binding enterprises like coconut and poultry suggested a limit of the net income upto ₹160.14/- and ₹2240.40/- respectively.

Sensitivity analysis on the value of RHS of linear constraints in optimal LP model presented in Table 4 revealed that, several changes could be suggest to increase the farm income, if some of the constraints are removed/modified. In the case of expenditure, third quartile was taken as the investment amount (₹63,106.4/-) for developing the LP model and the farmer is ready to invest more upto ₹ 65,641.09/- for which he would have received ₹ $0.85 /$ additional net return on investing every one rupee more. The maximum allowable increase and decrease of all the enterprises are also presented in Table 4 revealed that majority of the enterprises in the optimum model has achieved specified upper limit especially for tapioca, banana and black pepper. The optimum model of $S_{2}$ didn't suggest increase in population of

Table 3 Sensitivity analysis on the feasibility range of unit net income and available resources of enterprises in $S_{1}$ of AEU 8

\begin{tabular}{|c|c|c|c|c|c|c|c|c|c|}
\hline \multirow[b]{2}{*}{ S. No. } & \multirow[b]{2}{*}{ Name } & \multirow{2}{*}{$\begin{array}{l}\text { Final } \\
\text { value }\end{array}$} & \multicolumn{3}{|c|}{ Unit net income } & \multicolumn{3}{|c|}{ Available resources/ constraints } & \multirow{2}{*}{$\begin{array}{c}\text { Shadow } \\
\text { price }\end{array}$} \\
\hline & & & $\begin{array}{l}\text { Objective } \\
\text { Coefficient }\end{array}$ & $\begin{array}{l}\text { Max. } \\
\text { range }\end{array}$ & $\begin{array}{l}\text { Min. } \\
\text { range }\end{array}$ & $\begin{array}{c}\text { RHS } \\
\text { inequalities }\end{array}$ & $\begin{array}{l}\text { Max. } \\
\text { range }\end{array}$ & $\begin{array}{l}\text { Min. } \\
\text { range }\end{array}$ & \\
\hline 1 & Coconut & 15 & 142.2 & 197.12 & & 30 & - & 15 & 0 \\
\hline 2 & Jack & 2 & 438.25 & - & 215.17 & 2 & 17.29 & 0 & 223.08 \\
\hline 3 & Mango & 2 & 406.67 & - & 315.54 & 2 & 30.46 & 0 & 91.13 \\
\hline 4 & Gooseberry & 2 & 440.45 & - & 184.07 & 2 & 11.87 & 0 & 256.38 \\
\hline 5 & Tamarind & 2 & 517.15 & - & 257.6 & 2 & 6.46 & 0 & 259.55 \\
\hline 6 & Bread Fruit & 1 & 239.66 & - & 151.27 & 1 & 3.38 & 0 & 88.39 \\
\hline 7 & Cashew & 2 & 485.32 & - & 458.84 & 2 & 3.06 & 0 & 26.48 \\
\hline 8 & Arecanut & 3 & 282.21 & - & 134.83 & 3 & 27.78 & 0 & 147.38 \\
\hline 9 & Tapioca & 108 & 35.61 & - & 33.63 & 108 & 375.05 & 40 & 1.98 \\
\hline 10 & Banana & 47 & 190.48 & 201.47 & 151.42 & 60 & - & 47 & 0 \\
\hline 11 & Pepper & 10 & 223.15 & - & 130.81 & 10 & 78.66 & 0 & 92.34 \\
\hline 12 & Ginger & 8 & 7.22 & - & 5.24 & 8 & 552.5 & 0 & 1.98 \\
\hline 13 & Turmeric & 7 & 6.11 & 9.69 & - & 12 & - & 7 & 0 \\
\hline 14 & Papaya & 13 & 89.65 & - & 68.17 & 13 & 143.68 & 5 & 21.48 \\
\hline 15 & Moringa & 2 & 36.8 & - & 24.25 & 2 & 61.41 & 1 & 12.55 \\
\hline 16 & Colocasia & 5 & 18.62 & 23.42 & - & 14 & - & 5 & 0 \\
\hline 17 & Dioscorea & 12 & 33.7 & - & 29.08 & 12 & 320.88 & 0 & 4.62 \\
\hline 18 & Amorphophallus & 18 & 61.4 & - & 34.25 & 18 & 258.66 & 3 & 27.15 \\
\hline 19 & Sapota & 1 & 142.86 & 184.31 & - & - & - & - & - \\
\hline 20 & Annona & 1 & 255.23 & - & 199.34 & 1 & 34.01 & 0 & 55.89 \\
\hline 21 & Guava & 2 & 558.45 & - & 390.25 & 2 & 25.01 & 1 & 168.2 \\
\hline 22 & Vegetables & 2 & 3647.55 & - & 3312 & 2 & 4.71 & 1.26 & 335.55 \\
\hline 23 & Home & 1 & 0 & - & - & 1 & 1.41 & 0 & 0 \\
\hline 24 & Expenditure & 28792.68 & - & - & - & 28820.03 & 31154.85 & 20252.56 & 1.05 \\
\hline 25 & Total Area & 1450.48 & - & - & - & 1800 & - & 1642.98 & 0 \\
\hline 26 & Interspace & 390.27 & - & - & - & 677.44 & - & 527.26 & 0 \\
\hline
\end{tabular}

Journal of Experimental Biology and Agriculture Science http://www.jebas.org 
majority of enterprises even if the shadow prices were very high.

Homestead land area in the model was found to be an abundant resource and non binding and hence shadow price was observed as zero. The shadow price is always zero for non binding enterprises. However, an increase in the value of the enterprise will give more return, but only at the expense of other, more remunerative enterprises. The optimum model of $S_{2}$ suggested 33.30 per cent increase in net return over the existing plan with the use of lesser cultivable area from the specified limit in the homesteads with maximum population of the enterprises as observed from sensitivity analysis is an indication to increase the cropping intensity. This may also be viewed in different way that enhancement of farm income by increasing the population of enterprises, that have not reached the maximum allowable range in the optimum model in the recommended area.

\section{Conclusion}

The optimum model worked out for $\mathrm{S}_{\mathrm{I}}$ in AEU8 consisted of binding solution for almost all the enterprises except some enterprises like coconut and banana with 25.30 per cent

Table 4 Sensitivity analysis on the feasibility range of unit net income and available resources of enterprises in $\mathrm{S}_{2}$ of AEU 8

\begin{tabular}{|c|c|c|c|c|c|c|c|c|c|}
\hline \multirow[b]{2}{*}{ S. No. } & \multirow[b]{2}{*}{ Name } & \multirow{2}{*}{$\begin{array}{l}\text { Final } \\
\text { value }\end{array}$} & \multicolumn{3}{|c|}{ Unit net income } & \multicolumn{3}{|c|}{ Available resources/ constraints } & \multirow{2}{*}{$\begin{array}{c}\text { Shadow } \\
\text { price }\end{array}$} \\
\hline & & & $\begin{array}{l}\text { Objective } \\
\text { Coefficient }\end{array}$ & $\begin{array}{l}\text { Max. } \\
\text { range }\end{array}$ & $\begin{array}{l}\text { Min. } \\
\text { range }\end{array}$ & $\begin{array}{c}\text { RHS } \\
\text { inequalities }\end{array}$ & $\begin{array}{l}\text { Max. } \\
\text { range }\end{array}$ & $\begin{array}{l}\text { Min. } \\
\text { range }\end{array}$ & \\
\hline 1 & Coconut & 18 nos. & 156.26 & 160.14 & - & 40 & - & 18 & 0 \\
\hline 2 & Jack & 2 nos. & 835.28 & - & 267.36 & 2 & 2.13 & 1 & 567.92 \\
\hline 3 & Mango & 3 nos. & 435.4 & - & 192.31 & 3 & 3.18 & 2 & 243.09 \\
\hline 4 & Gooseberry & 2 nos. & 246.18 & - & 171.29 & 2 & 2.21 & 0 & 74.89 \\
\hline 5 & Tamarind & 2 nos. & 583.11 & - & 252.69 & 2 & 2.14 & 1 & 330.42 \\
\hline 6 & Bread Fruit & 2 nos. & 254.01 & - & 140.78 & 2 & 2.25 & 1 & 113.23 \\
\hline 7 & Cashew & 3 nos. & 362.76 & - & 330.67 & 3 & 3.11 & 1 & 32.09 \\
\hline 8 & Tapioca & 80 nos. & 34.58 & - & 27.85 & 80 & 81.27 & 60 & 6.73 \\
\hline 9 & Clove & 1 no. & 512.22 & - & 211.6 & 1 & 1.17 & 0 & 300.62 \\
\hline 10 & Banana & 62 nos. & 160.55 & - & 141.68 & 62 & 62.25 & 46.86 & 18.87 \\
\hline 11 & Nutmeg & 1 no. & 499.53 & - & 321.6 & 1 & 1.11 & 0 & 177.93 \\
\hline 12 & Pepper & 18 nos. & 200.23 & - & 101.7 & 18 & 18.35 & 0 & 98.53 \\
\hline 13 & Ginger & 3 nos. & 7.16 & - & 6.26 & 3 & 8.67 & 0 & 0.9 \\
\hline 14 & Curry Leaf & 1 no. & 51.53 & - & 16.7 & 1 & 3.13 & 0 & 34.83 \\
\hline 15 & Papaya & 20 nos. & 103.92 & - & 68.01 & 20 & 20.52 & 2 & 35.91 \\
\hline 16 & Moringa & 2 nos. & 69.79 & - & 52.33 & 2 & 2.68 & 0 & 17.46 \\
\hline 17 & Colocasia & 5 nos. & 17.36 & 31.82 & - & 12 & - & 5 & 0 \\
\hline 18 & Dioscorea & 12 nos. & 26.36 & - & 25.66 & 12 & 13.38 & 8 & 0.7 \\
\hline 19 & Amorphophallus & 10 nos. & 142.28 & - & 53.26 & 10 & 10.67 & 2 & 89.02 \\
\hline 20 & Sapota & 2 nos. & 202.68 & - & 172.74 & 2 & 2.21 & 1 & 29.94 \\
\hline 21 & Annona & 2 nos. & 250.92 & - & 221.86 & 2 & 2.16 & 1 & 29.06 \\
\hline 22 & Bilimbi & 2 nos. & 70.52 & - & 31.51 & 2 & 3.13 & 0 & 39.01 \\
\hline 23 & Guava & 1 no. & 270.48 & - & 212.13 & 1 & 1.17 & 0 & 58.35 \\
\hline 24 & Pineapple & 10 nos. & 16.04 & - & 11.34 & 10 & 13.13 & 0 & 4.7 \\
\hline 25 & Vegetables & 2 nos. & 2180.94 & 2240.4 & 2128.06 & 3 & - & 2 & 0 \\
\hline 26 & Goat & 4 nos. & 7751.5 & - & 4652.84 & 4 & 4.01 & 3.54 & 3098.66 \\
\hline 27 & Poultry & 6 nos. & 865.17 & 1206.16 & - & 15 & - & 6 & 0 \\
\hline 28 & Home & 1 no. & 0 & - & - & 1 & 2.71 & 0 & 0 \\
\hline 29 & Expenditure & 63064.5 & & & & 63106.4 & 65641.09 & 63064.45 & 0.85 \\
\hline 30 & Total Area & 1127.31 & & & & 1800 & - & 1127.31 & 0 \\
\hline 31 & Interspace & 377.81 & & & & 935.69 & - & 377.81 & 0 \\
\hline
\end{tabular}


enhancement in net return as compared to net return from the existing plan. The optimum model for $\mathrm{S}_{2}$ HFS was also similar to that of $S_{1}$ with non-binding solution for coconut and poultry with 31.30 per cent increase in net return. The result of LP indicated that intercropping area was an abundant resource in the optimal plan of all cropping systems. It was also found that even if income from livestock was high, farmers preferred to have the intercrops and allied enterprises which need less management practices and labour.

The present study developed statistical models for the existing cropping systems in homesteads and LP model suggests that farm income could be further enhanced by increasing cropping intensity and by removing the most uneconomical and less important enterprises in the existing plan with due importance to food security.

\section{Acknowledgement}

Research paper based on a thesis, "Statistical models for profit maximization of homesteads in Kerala" accepted by the Kerala Agricultural University for the award of Master's degree in Agricultural Statistics.

\section{Conflict of Interest}

Authors would hereby like to declare that there is no conflict of interests that could possibly arise.

\section{Reference}

Dantzig G (1991) Linear Programming and Extensions. Princeton, New Jersey: Princeton University Press. Retrieved from http://www.jstor.org/stable/j.ctt1cx3tvg

Dey G, Mukhopadhyay S (2010) Optimum Allocation of Resources in Different Situations of Resource Constraints. Economic Affairs 55: 153-158.

Hassan I, Ahamad P, Akhtar M (2015) Use of linear programming model to determine the optimum cropping pattern: a case study of Punjab. Electronic Journal of Environmental, Agricultural and Food Chemistry 4: 841-850.

Jayachandran N (1985) Optimization of enterprise combinations with special reference to garden land agriculture. M.Sc. (Ag) Thesis submitted to the Kerala Agricultural University, Thrissur, Pp. 82.

Jacob J, Nair MA (1999) Socio-economic characteristics of homestead farming in southern Kerala. Journal of Tropical Agriculture 37: 107-109.

Kurian V (2012) Kerala cuts new path in agro-ecological planning. The Hindu Business Line, 5 MAR. 2012, Pp.1.

Majeke F, Mubvuma MT, Makaza K, Mutambara J (2013) Optimum combination of crop farm activities: application of a linear programming model to a rural farmer in Zimbabwe. Greener Journal of Economics and Accountancy 2 : 58-61.

Mehta P (1992) Optimizing Techniques in Agriculture.CBS Publishers and Distributor, Delhi, India, Pp. 165. 